\title{
Business Innovations in the New Mobility Market during the COVID-19 with the Possibility of Open Business Model Innovation
}

\author{
Katarzyna Turoń *(D) and Andrzej Kubik *(D)
}

Citation: Turoń, K.; Kubik, A. Business Innovations in the New Mobility Market during the COVID-19 with the Possibility of Open Business Model Innovation. J. Open Innov. Technol. Mark. Complex. 2021, 7, 195. https://doi.org/ 10.3390/joitmc7030195

Received: 10 July 2021

Accepted: 25 August 2021

Published: 1 September 2021

Publisher's Note: MDPI stays neutral with regard to jurisdictional claims in published maps and institutional affiliations.

Copyright: (c) 2021 by the authors. Licensee MDPI, Basel, Switzerland. This article is an open access article distributed under the terms and conditions of the Creative Commons Attribution (CC BY) license (https:// creativecommons.org/licenses/by/ $4.0 /)$
Department of Road Transport, Faculty of Transport and Aviation Engineering, Silesian University of Technology, 8 Krasinskiego Street, 40-019 Katowice, Poland

* Correspondence: katarzyna.turon@polsl.pl (K.T.); andrzej.kubik@polsl.pl (A.K.)

Abstract: The current difficult situation in the world caused by the spread of the COVID-19 virus has led to the development of problems in many branches of the economy. However, it has significantly affected transport, which on the one hand, is the bloodstream of the economy and, on the other hand, creates a threat for virus infection. Thus, in various countries, different mobility-related restrictions during pandemic policies around the world have been introduced. What is more, plans for initiatives after lockdown have also started to appear. Moreover, not have only cities introduced appropriate management policies, but companies have also started providing logistics services, especially those offering new mobility solutions. We found a literature and research gap indicating the recording or combination of the different types of business practices and innovations used worldwide in new mobility companies in the case of a pandemic situation. Therefore, this article is dedicated to the business innovations that appear in the new mobility industry during the COVID-19 pandemic in connection to post-pandemic transportation plans in Asia, Europe, and America. In this work, we conducted two-level research based on the desk research and expert research methodologies. From the business point of view, the results show that car-sharing systems (most organizational practices) and ride-sharing services (most safety practices) have most adapted their business models to pandemic changes. In turn, bike-sharing services have implemented the fewest business practices and innovations. From the urban transport systems point of view, the results show that European authorities have proposed the most plans and practice projects for new mobility after the pandemic compared to Asia and America. The obtained results indicate, however, that business practices do not coincide with the authorities' plans for transport after the pandemic. Moreover, the results show a lack of complementarity between the developed practices and a reluctance to create open innovations in the new mobility industry. The article supports the management of new mobility systems in times of pandemic and in post-COVID reality.

Keywords: COVID-19 pandemic; sustainable urban transport systems; business practices and social issues; open innovations in new mobility; COVID-19 business practices; new mobility market; new mobility business innovations; transport in time of a pandemic; mobility management

\section{Introduction}

The spread of the COVID-19 pandemic has led to significant changes across all sectors of the economy. Among them, there is one sector that is treated as the bloodstream of the economy, and on the other hand, it has become a threat to society-the transport sector. The outbreak of the pandemic significantly changed the mobility of residents as well as their transport habits around the world. Detailed global mobility trends from 13 January 2020 to 8 July 2021 show that the first largest decline in mobility was over $50 \%$ in the first wave of the pandemic. Comparing the values of the decrease in travel for individual countries, in the case of Italy, the decrease was $54 \%$, for the United Kingdom it was $51 \%, 14 \%$ in the case of United States, and 18\% in Germany [1,2]. 
Mobility decreased due to the implementation of lockdowns, quarantines, and subsequent restrictions.

Appropriate and, above all, profitable functioning of the market has therefore become even more difficult for many companies, especially those that are the most popular among societies in recent years in the service sector-new mobility companies, which refer to all shared mobility services [3]. Based on the changes in mobility caused by the pandemic, they were forced to implement new activities in the form of various types of business practices to find a remedy for survival in the market. Even though management issues in enterprises during COVID-19 began to be considered by various scientists around the world, they mainly related to aspects of planning and forecasting new market needs [4-7]. Moreover, these studies mainly related to strategic management issues and focused on all economic branches, without a detailed approach to the new mobility sector. In parallel, we found research and a literature gap indicating a combination of the recording and comparison of the different types of practices and innovations used worldwide in urban transport systems and new mobility companies in the case of the pandemic and the post-pandemic reality. Therefore, we decided to perform two types of research to better understand the new mobility practices created during the COVID-19 pandemic against the background of local transport practices.

This work aimed to identify innovations in the form of practices implemented in all types of new mobility services during the COVID-19 pandemic. The results allowed the identification of both new mobility providers and transportation authority practices. What is more, the prepared research allowed the identification of the main areas of applied practice and of the service providers who implemented the largest number of innovations during the pandemic. The article provides detailed guidelines for improving the conditions of urban transportation systems in the post-lockdown period from a practical point of view. Moreover, the list of business practices and detailed results may provide support by outlining directions of action for operators of new mobility services who are faced with selecting or improving business models for their post-pandemic reality. What is more, the proposed analysis supports the process of the rapid adaptation of business models to the new market conditions arising from the COVID-19 pandemic. The article also refers to the forming of the innovations themselves. It analyzes in detail the various forms of implemented practices and points to the current approaches of the new mobility industry regarding the concept of open innovation.

The developed results refer to the markets of Europe, Asia, and America. The article supports the management of new mobility systems in times of pandemic and post-COVID reality.

The work is divided into six chapters. The first chapter is the introduction. The second presents a broad literature review relating to new mobility services and business models. The third chapter refers to the methodology of the conducted research. The fourth chapter contains the results of the desk research and expert analyzes. The discussion and summary are presented successively.

\section{Literature Review: New Mobility Business Models}

Transport mobility is defined as a society's activity to meet transport needs [8-11]. Mobility is related to all beliefs and opinions about movement [8,9]. The typical phenomenon of mobility refers to the classic meaning of all forms of movement, such as traveling in your own car, by walking, or transport by public transport equipped with conventional vehicles [10]. In turn, the concept of new mobility refers to all kinds of activities leading to balancing transport in cities and supporting economic growth, contributing to the improvement of living standards of residents and other transport users, as well as the environment protection and the development of urban and regional transport [11]. The significant interest in new mobility services is closely related to the subject of sustainable transport. New mobility services are based on business models that comply with assumptions of the idea of sustainable transportation by covering three interdependent key dimensions as 
economic, environmental, and social aspects [12,13]. Moreover, the link between human and technical resources and, at the same time, respect for natural resources, is closely aligned with the sustainable development goals set out in the United Nations 2030 Agenda called Sustainable Development Goals (SDGs) [14]. According to the SDGs, sustainable mobility issues are related to [14]:

- SDG 3 on health and well-being;

- $\quad$ SDG 7 on affordable and clean energy;

- $\quad$ SDG 8 on decent work and economic growth;

- $\quad$ SDG 9 on resilient infrastructure and innovation;

- SDG 11 on sustainable cities and communities;

- SDG 12 on sustainable consumption and production (ending fossil fuel subsidies).

Based on the assumptions of the SDGs, the concept of new mobility is associated with offering various forms of transport such as [15-17]:

- Electromobility and mobility using alternative fuels, including hydrogen fuels;

- Mobility-as-a-Service (MaaS) - booking of vehicles or on-demand journeys made available through mobile applications.

Electro-mobility and the use of vehicles fueled by alternative fuels apply to urban mobility in regard to journeys offered using public transport, individual vehicles, and vehicles available for on-demand services, while MaaS describes a shift away from personally owned transportation modes and mobility provided as a service [18]. MaaS is offered by operators of transit network companies, among others, in the form of ride-hailing and ride-sourcing. MaaS includes all services provided by operators such as Uber, Grab, or myTaxi that match passengers with drivers of vehicles for hire [19].

Shared mobility services constitute a separate group of systems that allow private users to rent a vehicle from an automated, self-rental city located in the city for a short time [19]. This kind of rental offers vehicles such as bicycles, scooters, mopeds, and cars. Most of them also provide vehicles powered by electric drives. The main idea of using this type of service is to give users the possibility of renting vehicles for minutes [20]. The main advantage of shared mobility vehicles is their availability [21]. This means that when the user wants to rent the vehicle, there is no need to contact the customer service office or to take part in the complicated registration process [21]. Thus, the main features of shared mobility systems can be considered to be their availability to the public by improving transport accessibility. Shared mobility is also treated as an alternative to owning a household vehicle, especially in economically challenging times such as the current COVID-19 crisis. The shared mobility market is developing very quickly and is growing in value. At the end of 2020, the global shared mobility market size was estimated at USD 251 billion [22]. From the point of view of individual market segments, bike-sharing services are characterized by the biggest fleet size. There are 1608 bike-sharing systems worldwide, with 18.2 million bicycles available for users [21]. From the point of view of car-sharing services, the fleet size reaches 332,000 vehicles are more than 23.8 million car-sharing registered users $[23,24]$. It is estimated that globally by 2025 , there will be 36 million users using car-sharing services [23]. Furthermore, the scooter-sharing system market is expected to be valued at USD 300 billion to USD 500 billion in 2030 [23].

In line with the growing trend of new mobility, increasingly, operators have appeared on the service market offering their ride-sharing and shared mobility services. Each of these services can be provided in business-to-business, business-to-consumer, and peer-topeer systems. In the case of shared mobility services, we also distinguish various types of functioning special business models. The comparison of these models is presented in Table 1. 
Table 1. Comparison of business models in new mobility systems.

\begin{tabular}{cccc}
\hline & \multicolumn{3}{c}{ Business Models } \\
\cline { 2 - 4 } System Type & $\begin{array}{c}\text { Station-Based } \\
\text { (Round-Trip) }\end{array}$ & One-Way & $\begin{array}{c}\text { Free-Floating } \\
\text { (Dockless) }\end{array}$ \\
\hline Car-sharing & $\times$ & $\times$ & $\times$ \\
Bike-sharing & $\times$ & & $\times$ \\
Scooter-sharing & & $\times$ \\
Moped-sharing & & $\times$ \\
Ride-hailing & & $\times$ \\
Ride-sharing & & $\times$ \\
Ride-sourcing & & & $\times$ \\
\hline
\end{tabular}

Source: author's own collaboration based on [21-31].

Users of the first type of system (station-based) can rent a vehicle at point A of a city and are required to return that vehicle to the same location. This type of system is similar to classic car rental or bike rental systems [24-26].

The second type of system (one-way) appears to only be related to car-sharing services. In the one-way system, cars can be rented in point $A$ and returned to another point within the city defined by the operator [27]. Usually, this type of sharing is based on zones (parks) where rented vehicles can be returned.

The third sharing type seems to be the most user-friendly. In the free-floating system, it is possible to rent a vehicle in point $\mathrm{A}$ and return it to $\mathrm{B}$ in the city/metropolis within the area covered by the operator [27].

Basic information related to these business models and the functioning of these new mobility solutions is particularly important when examining the processes of implementing various types of innovation in mobility management $[28,29]$. In this case, the practices implemented during the COVID-19 pandemic and post-pandemic plans on the level of public transportation and new mobility services, considered as innovations, were analyzed.

\section{Methodology}

To learn about the current COVID-19 practices in the new mobility market, two parts of research were proposed. The first part was related to the performance of research conducted using the desk research method and was related to the background of the functioning of transport in selected countries during the COVID-19 pandemic. The second part, in turn, was dedicated to the performance of expert research conducted among new mobility operators to identify the innovations they provided during the pandemic.

Desk research (secondary study) is a method that consists of the analysis of available data sources, including their compilation, mutual verification, and processing [32-34]. Desk research is involved in collecting data from existing resources; hence, it is often considered a low-cost technique [32-34]. The desk research method consists of five consecutive steps covering the process from defining the research objective to performing the analysis. The detailed process is presented in Figure 1.

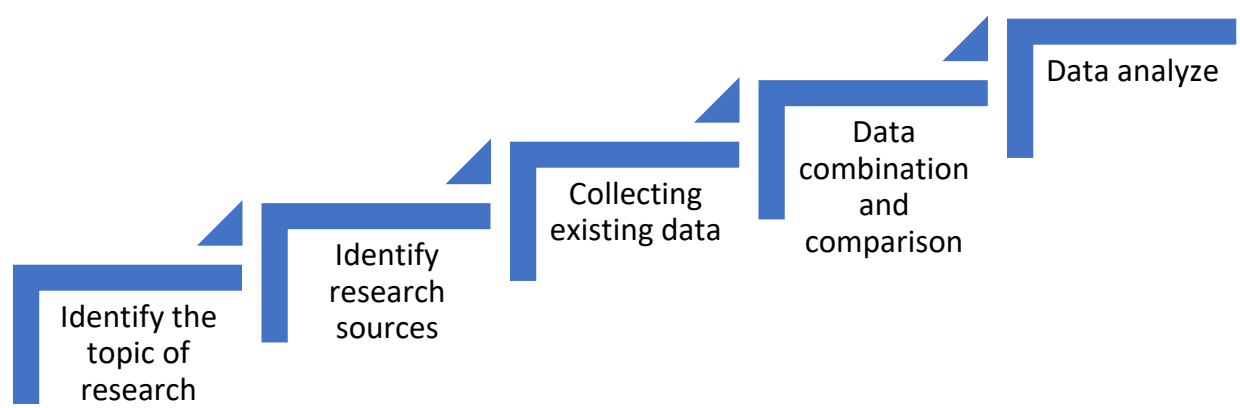

Figure 1. Desk research method process. 
The desk research method is divided into internal or external research [32-34]. Additionally, its application is to answer the questions "what?", "why?", and "how?" [32-34]. Thanks to the use of this method, it is possible to do a wide diagnosis by obtaining reliable data in a short time and in an economical way [32-34]. It is also a perfect tool for preliminary research into new market phenomena $[35,36]$. Since the coronavirus pandemic is such a phenomenon, it was decided upon to use this methodology.

According to presented assumptions, reference was made to check what types of practices, laws, and orders have been implemented by various countries from the European, Asian, and American continents concerning the functioning of transport during the pandemic. Practices from selected world cities were included and compared to the study referred to the first wave of the pandemic that occurred in the period up to May 2020. Desk research analysis was proposed to check the background for the functioning of new mobility companies.

The second part of the analysis was performed by using expert research. Expert research is one of the key methods of foresight [37]. Initiatives of this type aim to create medium- and long-term visions with the involvement of specialists in each field [38] -in the case of this article, the experts would be the new mobility providers. The planning of the research scenario and the research questions occurs thanks to the previously performed analysis of the secondary data (desk research) [37-39].

In line with the assumptions about the "perfect" respondent, the experts in the expert research portion were invited to the study in order to include experts with substantive knowledge in the field of new mobility and who had the ability to cope when faced with an uncertain extension of substantive knowledge into the future and the ability to imagine future activities [38]. Following the assumptions regarding the minimum number of experts, 50 representatives who were new mobility service providers were invited to the study. The research sample size was confirmed to be statistically corrected and representative. The minimum number of respondents $\operatorname{Exp}_{\min }$ was determined using Equation (1) [40]:

$$
\operatorname{Exp}_{\text {min }}=0.5 \cdot\left(\frac{3}{\gamma}+5\right)
$$

where: $\gamma$-denotes statistical compliance with the level of $10 \%$.

$$
\operatorname{Exp}_{\min }=\min .18 \text { experts }
$$

Detailed data on the research sample are presented in Table 2.

Table 2. Respondents' data.

\begin{tabular}{ccc}
\hline System's Type & Number of Respondents & Country \\
\hline Car-sharing & 18 & \\
Bike-sharing & 12 & China, France, Germany, Italy, \\
Scooter-sharing & 8 & Malaysia, Poland, Singapore, Spain, \\
Moped-sharing & 6 & United States of America \\
Ride-services & 6 & \\
\hline
\end{tabular}

Source: author's own collaboration.

The countries represented by the experts are consistent with the countries surveyed in the desk research section. Moreover, the indicated countries are characterized by the high popularity of new mobility services [41].

Due to the pandemic period, the study was conducted based on an online questionnaire. The survey was conducted using the Computer-Assisted Web Interview (CAWI) technique. As part of the questionnaire, the main research questions were formulated, which were:

Q1: Has your company implemented new business practices because of COVID-19? Q2: What business areas were the practices implemented by your company related to? Q3: How innovative were the practices implemented by your company? 
Q4: Please describe what practices have been implemented in your company.

Q5: Did the implemented practices bring profits for your company?

Q6: Do you think that the implemented practices will still be present in your company after the end of the pandemic?

The analyses were conducted quantitatively and qualitatively. The obtained results are presented in the following chapters.

\section{Results}

The obtained results were divided into two parts. The first part is related to the desk research analysis and is presented in Section 4.1. The second part related to the use of the expert study methodology is presented in Section 4.2.

\subsection{Desk Research Analysis: Urban Transportation Situation and Mobility Practices during the} First Wave of COVID-19 Pandemic and Post-Pandemic Plans

The following sections present mobility practices, laws and orders, and the general transport background regarding the first wave of the COVID-19 pandemic until May 2020 and post-pandemic plans. The chapter presents the results from the point of view of several dozen selected cities from the continents of Asia, Europe, and America.

\subsubsection{Selected COVID-19 Mobility Practices in Asia}

COVID-19 has struck China's public transport system. On 23 January 2020, the central government of China imposed a lockdown on Wuhan city and other cities in Hubei province to quarantine the center of an outbreak of coronavirus disease [42]. The lockdown in Wuhan set the precedent for similar measures in other Chinese cities including Wenzhou, Hangzhou, Fuzhou, Harbin, and the whole of Jiangxi [42]. Many areas across China have implemented "closed management" ideas on a community basis. In most of the areas where this came into effect, villages, communities, and units in most areas would only keep one entrance and exit point open, and each household was allowed the limited number of entrances and exits. In some places, night-time access was prohibited, effectively a curfew, and in extreme cases, access was prohibited throughout the day [43]. In the case of lockdowns, Chinese provinces and cities ultimately suspended transit [44-46]. As services are restored, ridership is returning in some places but not to full levels. According to a survey conducted by the Institute for Transportation and Development Policy in early March in the megacity of Guangzhou, only $34 \%$ of the last underground and bus commuters were using public transit systems, while $40 \%$ had shifted to private cars, taxis, and ride-hailing, and the rest had resorted to walking and biking. In Hangzhou, the provincial capital of southeastern Zhejiang province, a survey at the end of March found that the municipal bus system had recovered 50-60\% regular ridership [46]. Some buses have introduced new guidelines regarding the distance between traveling passengers. Each operating bus must be disinfected at least twice a day, once before leaving the depot and once after returning, and each operating bus must be disinfected more often in key risk areas such as routes departing from airports. Passenger temperatures are also checked before boarding. Some city bus operators, e.g., in Beijing and Shenzhen, even encouraged people to use identifiable payment methods such as WeChat, Alipay, or transit to payment cards, instead of cash. These payment methods reduce the risk of exposure and help local authorities track possible contacts and quickly inform passengers and relevant communities if a passenger is diagnosed with COVID-19. Shanghai has put QR codes on its buses and encourages passengers to scan and register their contact details [46].

The authorities prompted the operators to create new on-demand (on-request) bus lines during the pandemic [46]. They are supported by mobile applications after a user's request to travel. Supported by mobile applications, these lines have been developed specifically for new travel patterns. A route is created based on the initial and final location with reserved seats for all passengers after exceeding the demand threshold. By the end 
of March, the Beijing Public Transport Group had opened 173 custom routes based on massive surveys among companies and the public [46].

The pandemic has again aroused interest in sharing bicycles in free-floating or dockless systems. Importantly, before the emergence of an epidemic, this kind of system aroused growing resentment among users and generated many problems [46]. According to Meituan, Hello-Bike, and Didi Bike, the number of trips in Beijing increased by $120-187 \%$ compared to before the pandemic. Moreover, the distance that users use these bicycles for has also extended [46]. The average distance traveled by a user in Beijing increased by approx. $3 \mathrm{~km}$ for a given journey, which is a model of $69 \%$ concerning the journeys conducted before the pandemic [47]. On the other hand, a study from Nanjing shows that the pandemic has verified the availability of some bike-sharing stations. The results show that stations close to hospitals, health centers, and places of religion became the most frequented [47].

The Chinese Center for Disease Control has even recommended a form of public transport with the lowest risk of contracting a virus [46,47]. Local municipalities and companies have also supported this trend and have taken steps to ensure the availability and safety of shared bicycles. Meituan has taken the initiative to disinfect all bicycles on the streets in the cities where they drive, regardless of the brand, and other companies have followed suit $[46,47]$.

In Singapore, amid the COVID-19 outbreak, authorities have urged commuters to avoid nonessential travel to reduce commuter numbers on public transport [48]. Additionally, all commuters who are not feeling well are advised to not use public transport [48]. All commuters have to have a mask. Simultaneously, public transport operators have stepped up cleaning efforts on buses, trains, MRT stations, and bus interchanges [48]. Safe distancing stickers labeled "Please do not sit here" and "Please stand here" were progressively rolled out on all trains, train stations, buses, bus stops, and bus interchanges [48]. The maintenance of high hygiene standards is confirmed by the results of a survey that indicated that only $22 \%$ of respondents living in Singapore $(n=459)$ stated that they would not like to travel by public transport [48]. Furthermore, shared mobility services have been offered, and operators ensure the highest hygiene and disinfection standards of vehicles. Moreover, during COVID-19, Singaporean authorities noticed the need for the faster acceleration of transport and mutual integration. Accordingly, the Singapore Mobility Challenge project was accelerated [48].

In Taiwan, full downtime was not needed, and the pandemic had little impact on everyday life. Additionally, the shared mobility sector is growing steadily [49]. For example, a local scooter-sharing provider, WeMo, scored 25,000 rides per day per city, which was higher than before the pandemic and generated 15\% growth month-over-month [49].

\subsubsection{Selected COVID-19 Mobility Practices in Europe}

In the case of Europe and the first COVID-19 wave, Italy was a country with a vast spectrum of coronavirus activity. Due to the disease's spread since 12 March 2020, the whole country was under lockdown. After a complete ban on movement and leaving the house only in justified cases, short-term vehicle rentals are currently being restored [50,51].

Furthermore, temporary bike lines were introduced. Turin and Rome have announced plans to retain temporary bike lanes once lockdown measures begin to be lifted [51]. Keeping these bike lanes has been proposed to cut car congestion and help people maintain social distance.

In response to the COVID-19 outbreak, the municipality of Bologna launched the Urban Mobility Program and sped up the implementation of its cycling network [52]. The "Bicipolitana" network will consist of $493 \mathrm{~km}$ of cycle lanes integrated across the city [52].

Moreover, 10 other Italian cities also announced their post-COVID plans to improve mobility [52]. For example, Milan announced a model to reduce car use after lockdown. The city authorities want to introduce one of Europe's most ambitious schemes, reallocating street space from cars to cycling and walking, in response to the coronavirus crisis [52]. On 
the other hand, Naples, Genoa, Florence, and Bari want to launch permanent bike lanes traffic calming areas that are restricted to car traffic areas [52]. They also want to focus on launching more sharing mobility programs [52].

In the case of the United Kingdom, the European country with the second highest COVID-19 victims, Britain's Transport Minister, Grant Shapps, has admitted that the COVID-19 pandemic has contributed to a massive increase in bicycle commuters [53]. Due to that trend, London will accelerate creating new bike routes along major thoroughfares and rebuilding pedestrian routes by widening the pavement to allow physical distance and secure queuing in front of stores [53]. It is worth saying that in the United Kingdom, driving electric scooters was prohibited, and legalization is planned after developing legislation that would classify the scooter and its technical inspection rules [53]. It is currently planned to accelerate these procedures to enable the development of the scooter-sharing market in connection with plans to expand the number of cycle paths in which the state plans to invest GBP 2 billion [53].

Moreover, Edinburgh announced an action plan for safe walking and cycling. Amongst the proposals are street closures to vehicles, widened pavement, temporary cycle lanes, and bus priority measures [54]. Edinburgh had already begun implementing changes to help those making essential journeys and taking daily exercise by foot or bike to stay $2 \mathrm{~m}$ apart with road closures in some cities [54].

Meanwhile, Dublin is suspending loading bays and parking spaces in the Republic of Ireland to increase social distancing space by using removable plastic separators [54]. What is more, the city launched the COVID Mobility Programme [55]. The program addresses assumptions such as the improvement of pedestrian safety through the provision of additional space for movement and enhanced pedestrian areas, providing safer cycling facilities, providing additional space at many bus stops to facilitate social distancing while waiting, accommodating a certain level of car use calibrated with other transport needs, including possible additional parking provisions on the periphery of the city core area, and implementing various bus route changes required to enable the roll-out of cycling and walking measures [55].

In France, the authorities of the capital city of Paris want to create $650 \mathrm{~km}$ of postlockdown cycleways. Before the coronavirus crisis, the city had promised that every street would become cycle-friendly by 2024 [56]. On 30 April 2020, the French government presented a plan worth EUR 20 million to encourage cycling after lifting movement restrictions [32]. The goal is to prevent the massive transfer of citizens from public transport to car transport. According to state data, over $60 \%$ of Parisians' trips are no more than $5 \mathrm{~km}$ in distance, so it is advisable to opt-out of these trips by car [56]. Under these plans is also the removal of $72 \%$ of the city's on-street car parking spaces [56].

In Austria, to create more space for cyclists, the authorities of Vienna decided to launch temporary bicycle routes marked out on the streets [57].

In Belgium's capital city, Brussels authorities have announced a suite of measures to give pedestrians and cyclists more space in response to the COVID-19 outbreak [57].

\subsubsection{Selected COVID-19 Mobility Practices in America}

In the case of the United States, large metropolitan centers were particularly affected by the COVID-19 situation. New York City will close 40 miles $(64 \mathrm{~km})$ of streets to cars next month to provide more recreation opportunities and to expand pedestrians' space to maintain social distance [58]. The plan's goal calls for 100 miles of open streets, primarily near parks, as well as widened sidewalks and additional permanent bike lanes [58].

For comparison, the city of Montreal in Canada wants to completely redefine the urban plan of the city, informed by the effects of COVID-19 [59]. As a result, Montreal is to become a shared space open to various forms of transport, including shared mobility [59]. The existing additional lanes or parking lots are to be converted into green public spaces [59].

On the other hand, in the case of South America, in the Colombian capital city of Bogota, a system of additional temporary cycling routes between the western and central 
districts was briefly introduced. Bogota's mayor decided to permanently keep bicycle paths on the road on weekends and holidays [60]. The purpose is to help unload crowded BRT buses and, above all, to improve the environment and to reduce air pollution in the city [60].

Actions targeting bicycles have also been taken in Mexico. Mexico announced the implementation of a program for eight temporary routes for bicycles and electric scooters with a total length of $131 \mathrm{~km}$, operating from 9:00 a.m. to 9:00 p.m. [61]. The proposed system, which complements the existing network, has a radial and continuous system [61]. It consists of alternative corridors to public transport lines, serving areas with high demand for urban travel [61].

\subsection{Expert Research: Business Practices during a Pandemic in New Mobility Services}

Based on the responses received from operators, a summary of the results has been prepared.

From the point of view of the operators' openness to implementing new business practices due to the COVID-19, the answer was that $100 \%$ of the respondents implemented some kind of new practice in their companies.

From the point of view of the areas to which the implemented practices belonged, the respondents defined the areas of organization and safety. Detailed data are presented in Figure 2.

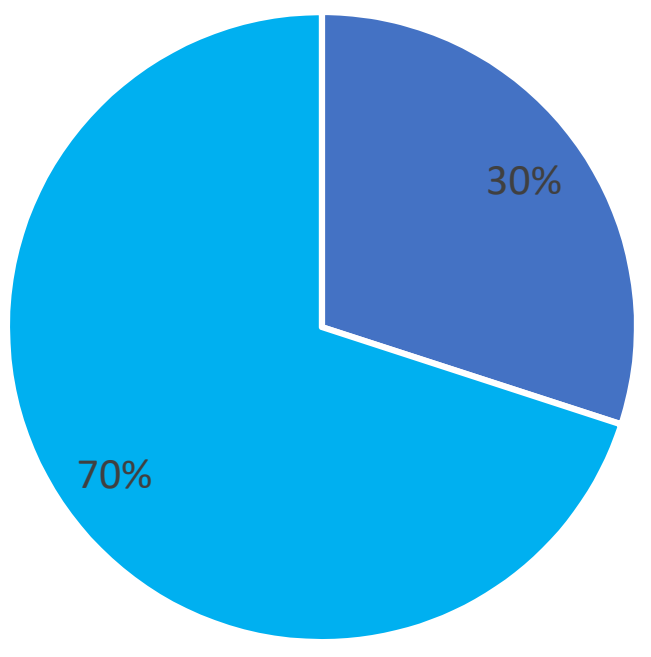

- Management issues

- Safety issues

Figure 2. Areas of implementation against pandemic practices in the new mobility market.

In the case of questions regarding the innovation level of the implemented practices, a 7-point Likert scale was used, where respondents expressed their opinions by providing answers from (1) absolutely non-innovative, (2) non-innovative, (3) probably non-innovative, (4) I do not know (5) probably innovative, (6) innovative, and (7) absolutely innovative. Detailed data are presented in Figures 3 and 4.

In turn, the implemented practices defined by the operators were classified in terms of aspects related to organization and management and safety areas, which were indicated by the respondents. The results are presented in Tables 3 and 4 as well as in Figures 5 and 6 . 


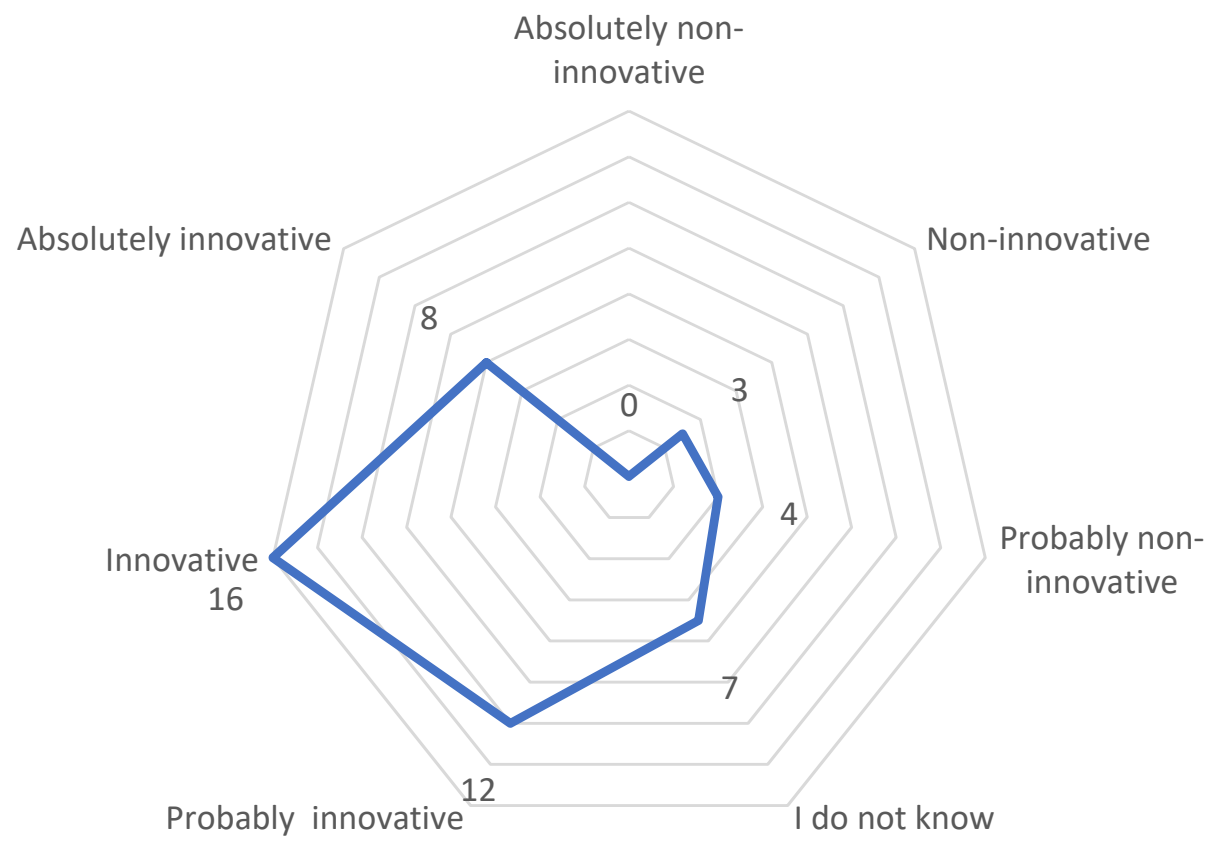

Figure 3. Innovation level of implemented practices.

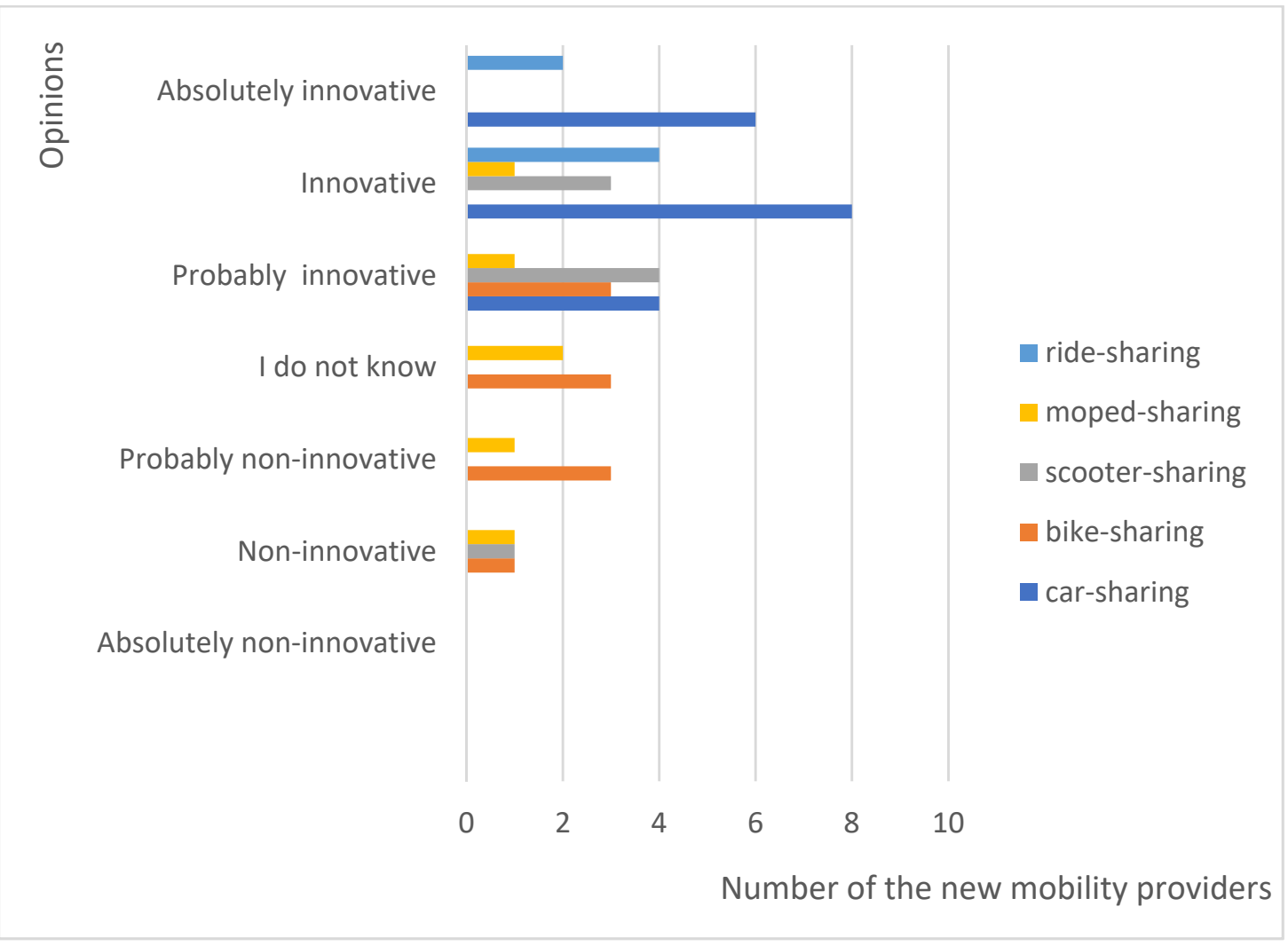

Figure 4. Innovation level of implemented practices broken down by types of service providers-detailed results broken down into new mobility sectors. 
Table 3. Comparison of business practices in new mobility systems-management and organizational issues.

\begin{tabular}{|c|c|c|c|c|c|}
\hline \multirow[b]{2}{*}{ Business Organizational Practices } & \multicolumn{5}{|c|}{ System's Type } \\
\hline & Car-Sharing & Bike-Sharing & $\begin{array}{l}\text { Scooter- } \\
\text { Sharing }\end{array}$ & $\begin{array}{l}\text { Moped- } \\
\text { Sharing }\end{array}$ & $\begin{array}{c}\text { Ride-Sharing } \\
\text { Services }\end{array}$ \\
\hline $\begin{array}{l}\text { Introduction of additional zones for } \\
\text { system operation }\end{array}$ & $x$ & & $\times$ & $\times$ & \\
\hline $\begin{array}{l}\text { Introduction of additional stations } \\
\text { (parking spaces) for vehicles from } \\
\text { the systems }\end{array}$ & $\times$ & & & & \\
\hline $\begin{array}{l}\text { Introduction of package services, } \\
\text { including long-term rentals }\end{array}$ & $x$ & $\times$ & $\times$ & $\times$ & $\times$ \\
\hline $\begin{array}{l}\text { Introduction of a new type of billing } \\
\text { method to choose from, e.g., per } \\
\text { kilometer or per minute of rental }\end{array}$ & $\times$ & & & & \\
\hline $\begin{array}{l}\text { Free memberships for } \\
\text { essential workers }\end{array}$ & $\times$ & $\times$ & $\times$ & $\times$ & \\
\hline Discounted rental fee & $\times$ & $\times$ & $x$ & $x$ & $\times$ \\
\hline
\end{tabular}

Source: author's own collaboration.

Table 4. Comparison of business practices in new mobility systems—safety issues.

\begin{tabular}{|c|c|c|c|c|c|}
\hline \multirow[b]{2}{*}{ Business Safety Practices } & \multicolumn{5}{|c|}{ System's Type } \\
\hline & Car-Sharing & Bike-Sharing & $\begin{array}{l}\text { Scooter- } \\
\text { Sharing }\end{array}$ & $\begin{array}{l}\text { Moped- } \\
\text { Sharing }\end{array}$ & $\begin{array}{l}\text { Ride-Sharing } \\
\text { Services }\end{array}$ \\
\hline Requirement to wear masks & $\times$ & & & & $\times$ \\
\hline $\begin{array}{l}\text { Requirement to wear } \\
\text { protective gloves }\end{array}$ & $x$ & & & & $\times$ \\
\hline $\begin{array}{l}\text { Requirement to disinfect vehicles and } \\
\text { their equipment }\end{array}$ & $\times$ & $x$ & $x$ & $x$ & $\times$ \\
\hline Vehicle ozonation & $\times$ & & & & $\times$ \\
\hline Need to open windows & $\times$ & & & & $\times$ \\
\hline $\begin{array}{l}\text { Need to provide ventilation in the } \\
\text { vehicle (air supply, air conditioning) }\end{array}$ & $\times$ & & & & $\times$ \\
\hline $\begin{array}{c}\text { Requirements for washing hands or } \\
\text { using sanitizer before and } \\
\text { after service }\end{array}$ & $\times$ & $\times$ & $\times$ & $x$ & $\times$ \\
\hline $\begin{array}{l}\text { Sharing the vehicle alone or with the } \\
\text { same small group only }\end{array}$ & $\times$ & & & & $\times$ \\
\hline Vehicle disinfection after each user & $\times$ & $\times$ & $\times$ & $\times$ & $\times$ \\
\hline $\begin{array}{l}\text { Sitting requirements (as far as } \\
\text { possible from the driver) }\end{array}$ & & & & & $\times$ \\
\hline
\end{tabular}

Source: author's own collaboration.

In the case of questions regarding the profit of the innovation level of the implemented practices, a 7-point Likert scale was used, where respondents expressed their opinions by providing answers from (1) absolutely not profitable, (2) not profitable, (3) probably not profitable, (4) I do not know, (5) probably profitable, (6) profitable, and (7) absolutely profitable. Detailed data are presented in Figures 7 and 8. 


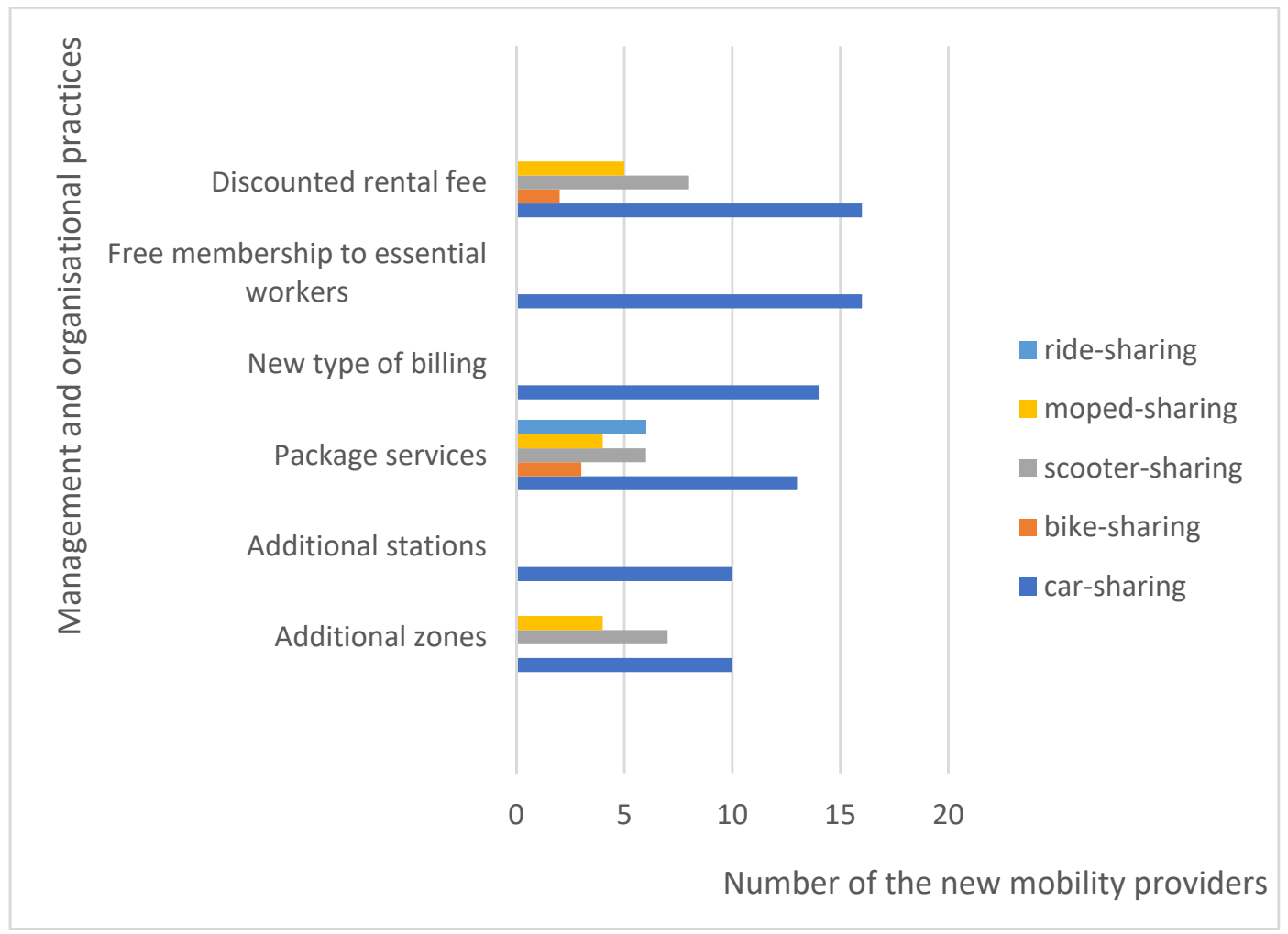

Figure 5. Management and organizational practices from the new mobility providers point of view—detailed results broken down into new mobility sectors.

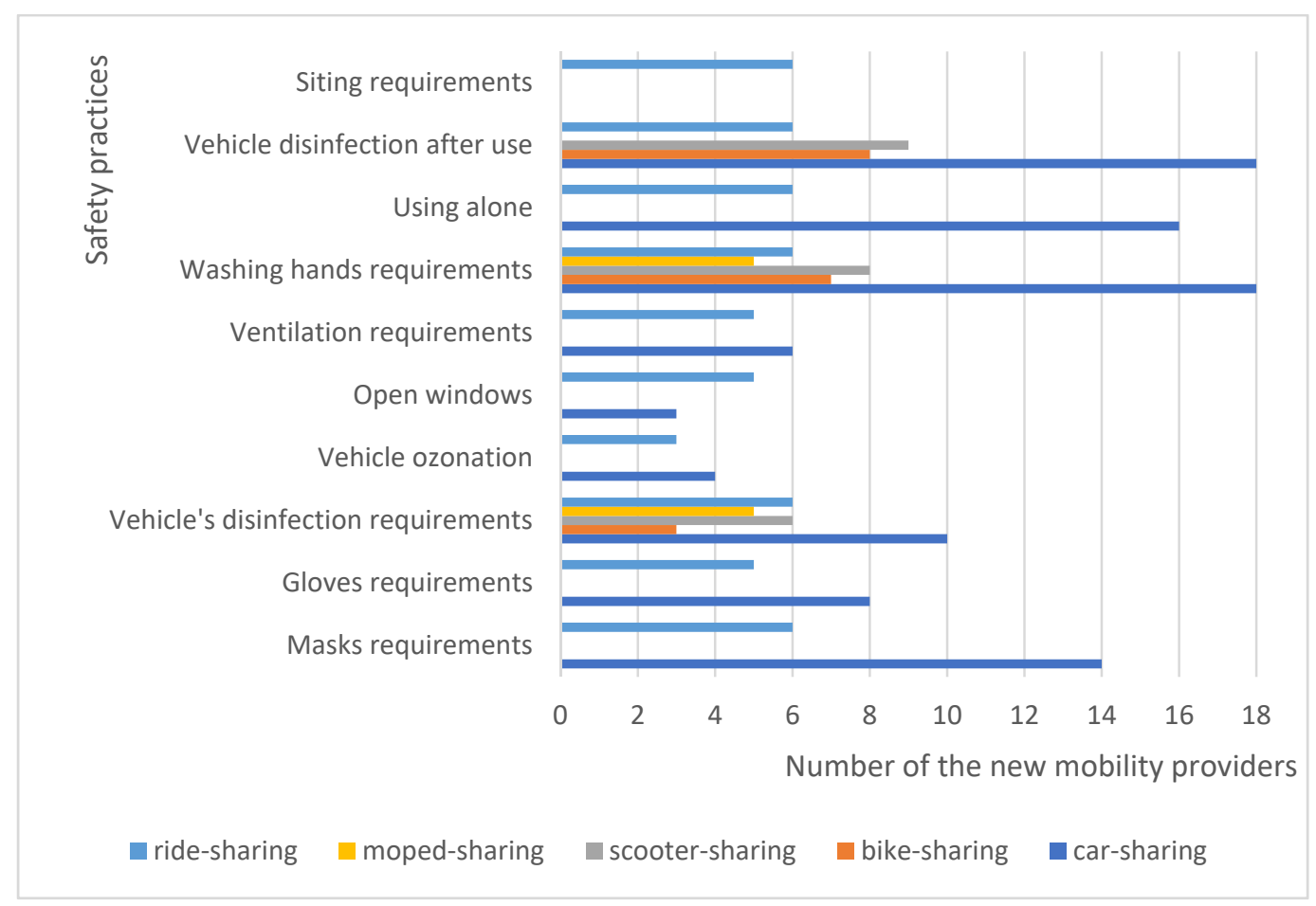

Figure 6. Safety practices from the new mobility providers' point of view-detailed results broken down into new mobility sectors. 


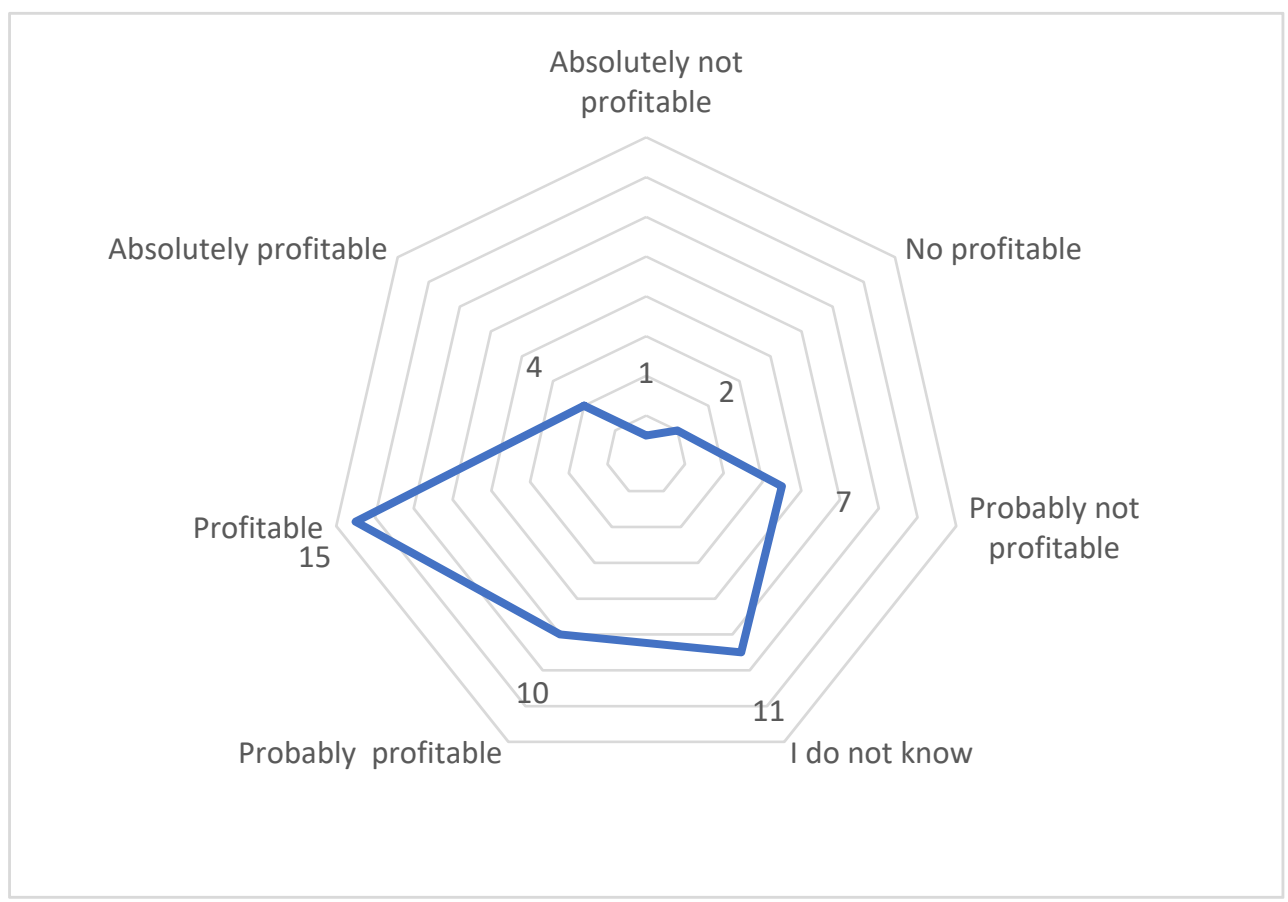

Figure 7. Profitability level of implemented practices.

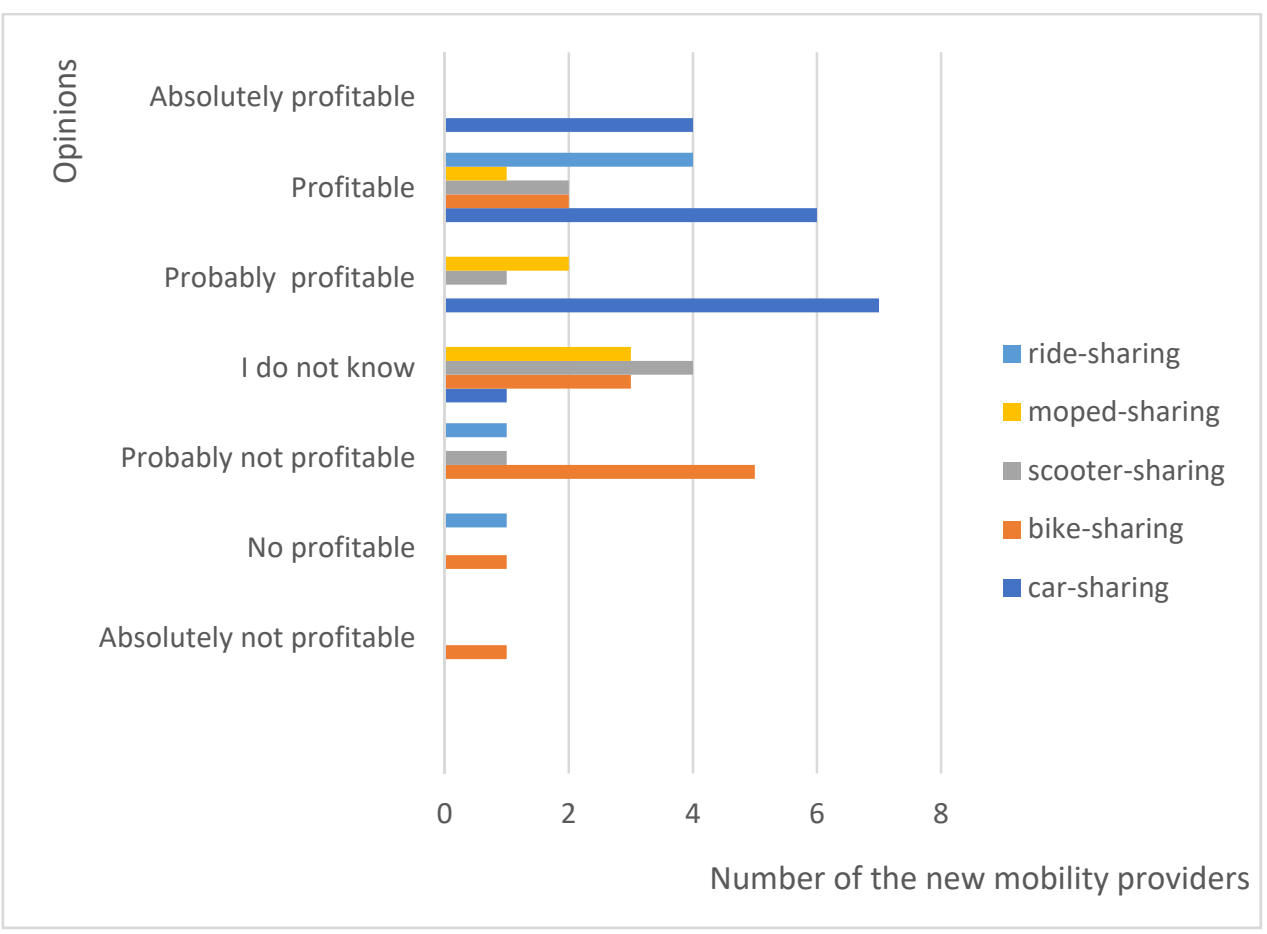

Figure 8. Innovation level of the implemented practices from the new mobility providers' point of view—detailed results broken down into new mobility sectors.

In the case of questions regarding the opinion of the possibility of the implemented practices remaining implemented after the pandemic period, a 7-point Likert scale was used, where the respondents expressed their opinions by providing answers from (1) absolutely impossible, (2) not possible, (3) probably not possible, (4) I do not know, (5) probably possible, (6) possible, and (7) absolutely possible. Detailed data are presented in Figures 9 and 10. 


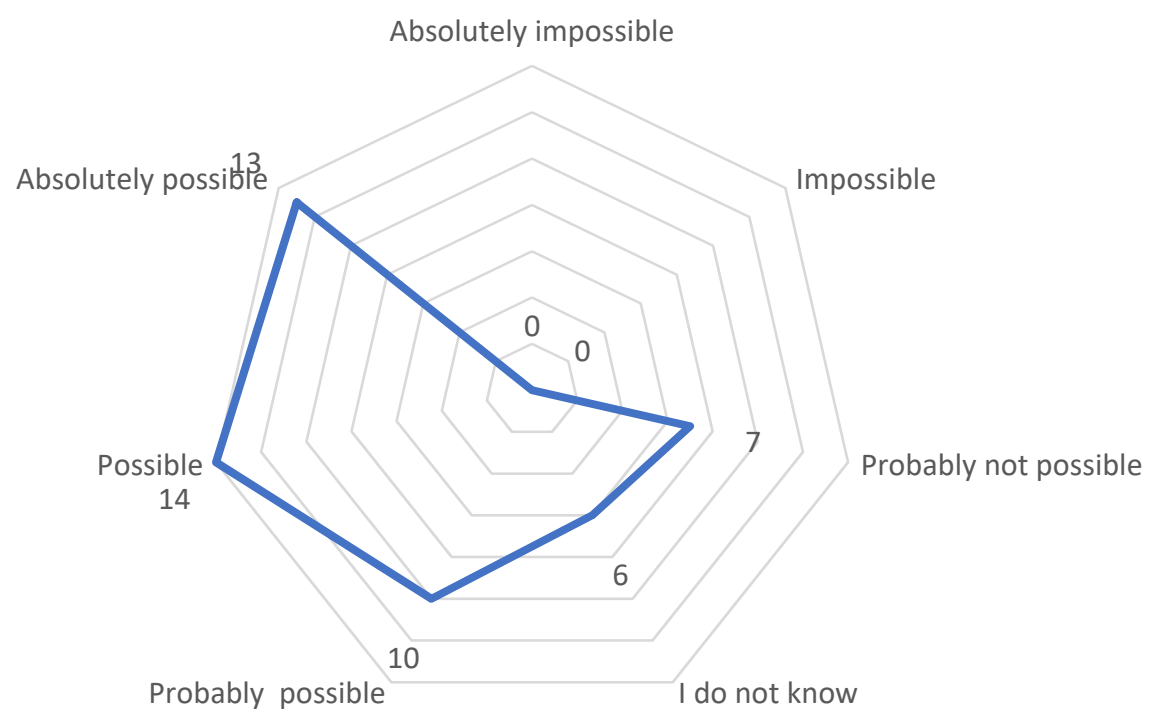

Figure 9. The possibility of the implemented practices remaining implemented in the new mobility market after the pandemic.

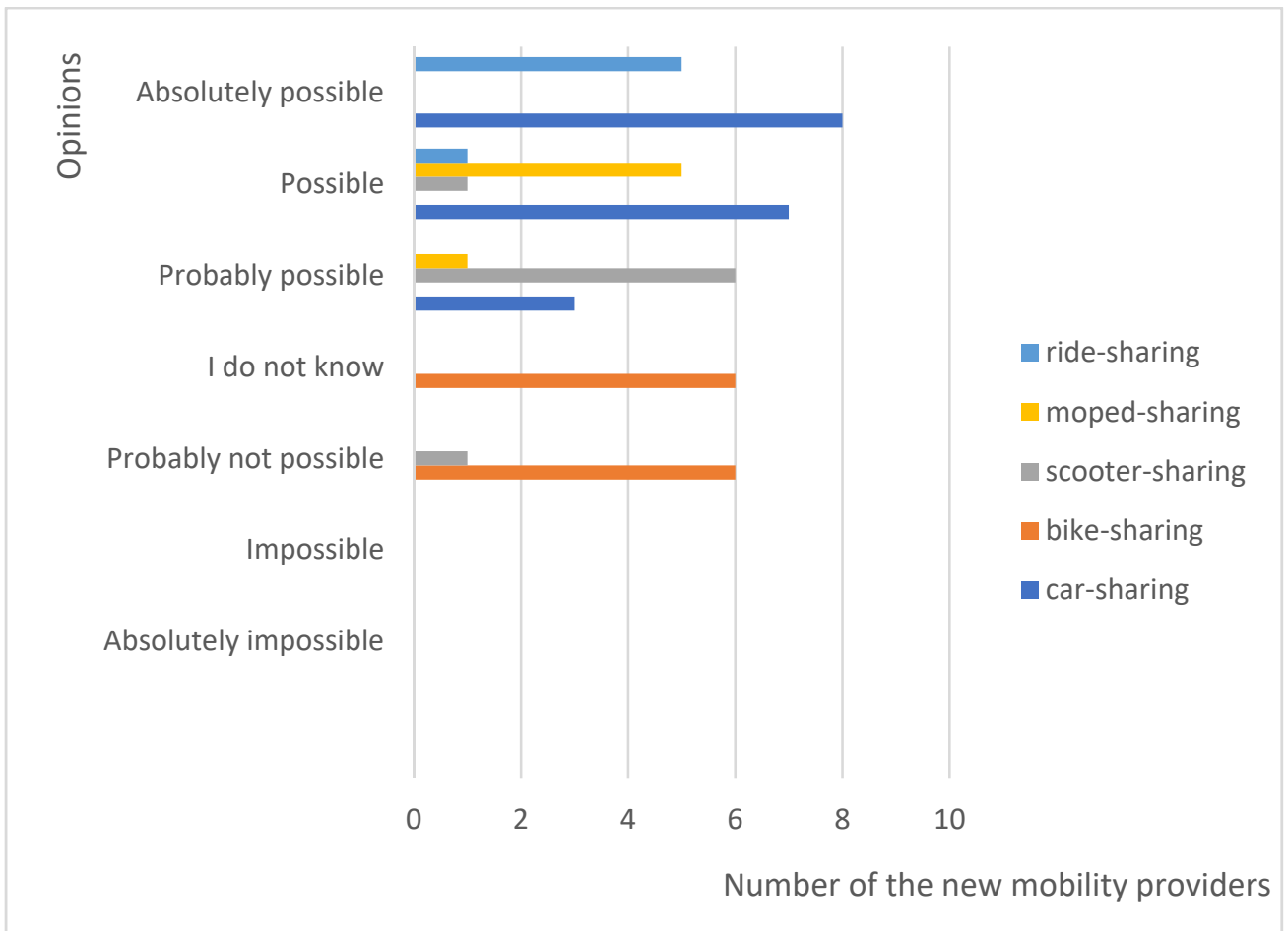

Figure 10. The possibility of the implemented practices remaining implemented in the new mobility market after the pandemic-detailed results broken down into new mobility sectors. 


\section{Discussion: Open Innovation, and Business Model Innovation}

The conducted research shows that the new mobility services industry, based on the three analyzed continents, i.e., Europe, Asia, and America, has adapted its services to pandemic conditions. The obtained results indicate that each of the analyzed new mobility sectors, i.e., car-sharing, bike-sharing, scooter-sharing, moped-sharing as well as ride-sharing and ride-hailing services, have implemented practices in their activities. A total of $70 \%$ of the implemented business practices were related to security aspects. In turn, $30 \%$ of the remaining practices concerned issues related to the appropriate approach to business management and organizational issues during the pandemic.

From the point of view of innovativeness of the implemented practices, it can be stated that the car-sharing and ride-sharing sectors have also implemented this type of practice the most. The results show that over $77 \%$ of car-sharing system operators admit that the practices that they implemented were absolutely innovative or innovative. In turn, in the case of ride-sharing, over $30 \%$ of the respondents considered the practices implemented during the pandemic to be absolutely innovative, and over $66 \%$ considered the implemented practices to be innovative. Interestingly, the practices implemented by the bike-sharing service providers were assessed as the least innovative. For over $58 \%$ of respondents, the implemented activities were not innovative or probably not innovative. It is worth emphasizing that no results were obtained from the respondents stating that the implemented practices were absolutely non-innovative. It can therefore be concluded that the pandemic situation increased the level of innovative development of enterprises in the new mobility industry.

A detailed analysis of the implemented practices shows that most management and organizational practices have been implemented in car-sharing systems. This means that the operators best adapted their systems to the outbreak of the pandemic and any restrictions that had been imposed. The implemented practices are related both to the issue of fleet management and the appropriate relocation of the vehicles or management of tariffs and price lists. Such results fully translate into the real market situation. For example, one of the main car-sharing operators, Free-Now, indicated that in April 2020, car-sharing trips decreased by $56 \%$ in Berlin and $62 \%$ in Hamburg, while the decrease in public transport travel was over $80 \%$ [62]. Moreover, the implemented practices also translated into increased demand after the first wave of the pandemic. In July 2020, in Germany, there were $45 \%$ more car-sharing trips than in April 2020 [62]. For example, in Hamburg, there were $55 \%$ more trips during this time [62]. In comparison, public transport in Berlin only gained back $20 \%$ of passengers in the same period [62].

It is worth noting that from the organizational point of view, the practices have been implemented by ride-sharing providers. Interestingly, market practices indicate that an appropriate approach to pricing issues as well as performance expectancy, facilitating conditions, and social influence are among the main factors influencing the use of ridesharing services during a pandemic [63]. What is more, regardless of customers, there is also the problem of the employees of ride-sharing services. The pandemic situation significantly limited the frequency of their courses and contributed to the problem of widespread distrust of the industry and the phenomenon of unemployment [64]. The results indicate a small dimension of practice in this sector of the new mobility industry, which may certainly translate into inadequate strategic management and deficiencies in the field of corporate social responsibility. It is worth emphasizing the need to validate their code of conduct by ride-sharing service providers in the post-pandemic period so that the industry can continue to develop in regard to other forms of new mobility.

When analyzing safety practices, contrary to management practices, ride-sharing service providers have implemented the most of them. Car-sharing services came second in the ranking. These results are related to the fact that for both services, journeys are conducted with the use of a car. Since the car is a vehicle with a closed surface in relation to, for example, a scooter or moped, it is important to implement various solutions enabling increased air ventilation. 
From the point of view of individual safety practices, it should be noted that the sector adhering the least to these practices was the bike-sharing sector. The results show that only $25 \%$ of bike-sharing operators implemented the need to disinfect their vehicles. For comparison, in the case of ride-sharing, it was 100\%, and for car-sharing, it was over 55\%.

When analyzing business practices from the point of view of profits brought to the operators of new mobility services, it should be noted that for 38\% of the entire industry, the practices were absolutely profitable or profitable, while $20 \%$ of the respondents judged the practices as possibly profitable. The results show that car-sharing and ride-sharing are the most profitable practices, and bike-sharing is the least profitable.

It is also worth emphasizing that more than half of the respondents assume that the practices implemented during the pandemic will remain in the enterprises after the pandemic period. In this case, car-sharing and ride-sharing companies also plan to leave as many of the currently implemented practices in place as possible. Interestingly, no results were obtained that indicated that leaving these practices in place would be impossible or absolutely impossible. This may indicate that the implemented practices allowed for the verification of the current business models of the new mobility market and allowed in the indication of which direction will transform them to a more innovative level.

Referring to the transport background in Asia, it can be concluded that in the Asian transportation market during the COVID-19 pandemic, it was not found that complete movement was prohibited. Governments developed some new recommendations and guidelines, such as the pursuit of the acceleration of transport, but none of the forms of transport were banned or mandated. Apart from Singapore, no specific programs have been developed regarding post-pandemic mobility.

Analyzing the European transportation market during the COVID-19 pandemic, it can be stated that European countries, only after the tested restrictions and implemented practices, have developed various types of plans and projects regarding post-pandemic mobility. Importantly, the proposed projects consider the limitation of the traffic caused by individual cars and mainly focus on the creation of infrastructure for bicycles, infrastructure for traffic calming, reshaping cities, and urban transport systems by focusing on pedestrians as well as practices in the field of activating the use of shared mobility services and the integration of transport services.

In turn, the American transportation market during the COVID-19 pandemic has not developed specific formalized plans or programs as in the case of Europe. On the other hand, it can be noticed that most of the plans in which the proposed practices come down to focus on changing the urban plan of cities and implementing solutions that are favorable to cyclists and pedestrians.

By linking city plans for post-pandemic periods and the practices implemented by operators, it can be concluded that cities have given too much particular focus to user safety practices at all. Moreover, very little attention has been paid to specific shared mobility initiatives in government decisions. Regarding any swing of ride-sharing and mopedsharing services, these services are completely overlooked. Furthermore, no references to electromobility and, for example, the safe use of vehicle charging stations from the point of view of possible future pandemics have been found. Interestingly, cities seem to mainly focus on developing policies and plans for bicycle transport but by targeting individual bicycle transport, not bike-sharing services. Unfortunately, when analyzing bike-sharing practicing, it can be stated that both organizationally and in terms of safety that they were the worst at dealing with the occurrence of pandemic conditions. In our opinion, the urban policies and transport plans in a post-pandemic reality do not fully take into account all forms of new mobility. We believe that city authorities did not analyze the actions taken by the new mobility industry in detail. We believe that the plans proposed by the government do not ensure the development and innovation of new mobility services, and we believe that some of the plans threaten the development of the new mobility industry.

Considering the business practices of new mobility service operators implemented during the COVID-19 pandemic as well as practices and city plans from the point of view 
of open innovation, it should be stated that the involvement in open innovation is very insignificant. When analyzing the implemented practices in detail, it should be stated that despite the high level of innovation, most of the implemented practices were closed innovations. Therefore, the implemented practices do not include an advanced form of cooperation with the external environment of enterprises. In fact, the only open innovation was the provision of free memberships to essential workers. The conducted research proves that the implemented practices in the new mobility industry do not have cooperation at the levels of knowledge exchange, experience, and ideas between enterprises, competitors, customers, and suppliers. Moreover, the discrepancies between company practices and municipal plans are indicative of an erroneous flow of information and insufficient cooperation at the company-local transport authority level. In our opinion, the new mobility industry is very distrustful. Despite many attempts to integrate transport around the world through joint transport models or the creation of public-private partnerships (for example in the case of rental companies co-financed by urban centers), mutual competition, not complementarity, is still visible. At this point, it is worth emphasizing that the new mobility industry derives from a sharing economy, and it is according to this that the principles of openness of data, resources, and services should be the basis for functioning $[65,66]$. It is worth emphasizing that in the times of the COVID-19 pandemic when the existence of all kinds of industries is threatened, the implementation of open innovations for the benefit of all of society is particularly important. The exchange of practices and business patterns can allow organizations to learn from each other in terms of how to react further in the face of an ongoing pandemic, but also in terms of how to prepare for other possible potential crises [67]. It is therefore worth emphasizing that despite the industry's resistance to "sharing", the current market situation related to the pandemic is an appropriate moment to implement open innovations. Thanks to this, it is not only possible to survive on the market, but also to ensure the long-term profitability of enterprises and the organization's resistance to unexpected crises, and that is the most important thing needed to achieve the real and sustainable development of the industry.

\section{Conclusions}

In conclusion, the research conducted in this study indicated that the new mobility industry has largely adapted its business model to the COVID-19 pandemic. The purpose of the study was fulfilled, which proves the results that each of the analyzed new mobility sectors have implemented business practices. Most practices focused on ensuring the safety of their clients and around business innovations from the point of view of company management. The research showed that the biggest changes in their models from the organizational point of view were implemented by the car-sharing industry, and from the safety point of view, most of the biggest changes were implemented by the ride-sharing industry. Interestingly, the smallest number of practices was implemented by the bikesharing sector.

Referring to the post-pandemic plans proposed by global government authorities, it should be emphasized that they do not translate into practices used by new mobility industries. It should be emphasized that the proposed transport plans in their current forms promote forms of transport that have not implemented a large number of practices in the field of user-safety in their activities (bike-sharing). Moreover, it is also worth pointing out that transport plans, apart from implementing the resilience vision, should also take into account the business profitability of transport solutions. In this case, there is also non-compliance because it was the car-sharing and ride-sharing services that obtained the greatest profitability from the implemented activities. It is worth noting that the proposed plans require reliable validation in terms of services provided by the industry, implemented safety and organization practices, and the real demand for services.

Moreover, from the point of view of possible further waves of virus spread and from the point of view related to those consequences, it is important to focus on transport solutions that are planned to be implemented after the pandemic period. It should therefore 
focus on an appropriate integration of a transport system to a consistent striving Mobilityas-a-System without creating the exclusion of transport, which has been enlarged over the course of the pandemic.

The conducted research showed that even though companies created innovations in the new mobility market, almost all of the innovations were closed innovations. Furthermore, city transport plans also fail to target the creation of fraudulent innovations. The results indicate that both the private new mobility sector and the public transport sector authorities do not cooperate at the levels of knowledge exchange, experiences, and ideas. In our opinion, there is therefore much to be done in terms of developing common policies for open innovation in new mobility concerning transport conditions.

This article provides detailed guidelines for improving the conditions of urban transportation systems in the post-lockdown period from a practical point of view. Moreover, the list of business practices and detailed results may provide support by outlining future directions of action for operators of new mobility services who are faced with selecting business models that are appropriate for their post-pandemic reality. What is more, the obtained results support the process of the rapid adaptation of business models to new market conditions arising from the COVID-19 pandemic. The article also provides a knowledge base for the lack of complementarity between the single forms of transport in the new mobility industry. It can be successfully used to convert business practices towards open innovation.

Therefore, our work can provide significant support for researchers in the development of their studies or assumptions for research and projects by filling the research gap that characterizes the business innovations created in the new mobility industry during the pandemic against the backdrop of global post-pandemic transport plans. There are some limitations associated with this article. The materials we collected during the desk research portion of the study come from various literature sources and data related to mobility patterns during the COVID-19 pandemic. Despite our special efforts, some important documents may have been omitted. On the other hand, in the case of the expert research portion, due to the limitations related to the pandemic, we were not able to acquire answers from more than 50 new mobility providers. This number is representative; however, in further studies, we plan to expand our group of experts with providers from additional countries to perform an even more complete global analysis of the new mobility market after successive waves of the pandemic.

Author Contributions: Conceptualization, K.T. and A.K.; methodology, K.T. and A.K.; software, A.K.; validation, K.T. and A.K.; formal analysis, K.T.; investigation, K.T.; resources, K.T.; data curation, K.T. and A.K.; writing—original draft preparation, K.T.; writing—review and editing, K.T. and A.K.; visualization, K.T.; supervision, K.T. and A.K.; project administration, K.T.; funding acquisition, K.T. All authors have read and agreed to the published version of the manuscript.

Funding: The research and analyzes performed for this article were funded by the Silesian University of Technology grant for support to start activities in a new research topic, as part of the InitiativeExcellence program Research University 12/010/SDU/10-22-01.

Institutional Review Board Statement: Not applicable.

Informed Consent Statement: Informed consent was obtained from all subjects involved in the study.

Data Availability Statement: The data presented in this study are available upon request from the authors.

Conflicts of Interest: The author declares no conflict of interest.

\section{References}

1. Apple Incorporation Mobility Report. Available online: https://www.apple.com/covid19/mobility (accessed on 18 November 2020).

2. Mobility during COVID-19. Available online: https://www.gstatic.com/covid19/mobility/2020-05-02_PL_Mobility_Report_en. pdf (accessed on 10 May 2020).

3. Kamargianni, M.; Li, W.; Matyas, M.; Schäfer, A. A critical review of new mobility services for urban transport. Transp. Res. Procedia 2016, 14, 3294-3303. [CrossRef] 
4. Donthu, N.; Gustafsson, A. Effects of COVID-19 on business and research. J. Bus. Res. 2020, 117, 284-289. [CrossRef]

5. Secinaro, S.; Brescia, V.; Calandra, D.; Biancone, P. Towards a hybrid model for the management of smart city initiatives. Cities 2021, 116, 103278. [CrossRef]

6. Gkiotsalitis, K.; Cats, O. Public transport planning adaption under the COVID-19 pandemic crisis: Literature review of research needs and directions. Transp. Rev. 2021, 41, 374-392. [CrossRef]

7. Campra, M.; Esposito, P.; Brescia, V. State of the Art of COVID-19 and Business, Management, and Accounting Sector. A Bibliometrix Analysis. Int. J. Bus. Manag. 2021, 16, 35-52. [CrossRef]

8. Mohan, D.; Tiwari, G.; Hensher, D. Mobility, Environment and Safety in Megacities: Dealing with a Complex Future. IATSS Res. 2000, 24, 39-46. [CrossRef]

9. Schafer, A.; Victor, D.G. The Future Mobility of the World Population. Transp. Res. Part A Policy Pract. 2000, 34, 171205. Available online: http:/ / citeseerx.ist.psu.edu/viewdoc / download?doi=10.1.1.500.7174\&rep=rep1\&type=pdf $($ accessed on 10 May 2020). [CrossRef]

10. Bieliński, T.; Kwapisz, A.; Ważna, A. Bike-sharing systems in Poland. Sustainability 2019, 11, 2458. [CrossRef]

11. Wiederkehr, P.; Gilbert, R.; Crist, P.; Caïd, N. Environmentally Sustainable Transport (EST): Concept, Goal, and Strategy-The OECD's EST Project. Eur. J. Transp. Infrastruct. Res. 2004, 4, 11-25.

12. Elkington, J. Enter the triple bottom line. In The Triple Bottom Line; Routledge: London, UK, 2013; pp. 23-38.

13. Bansal, P. The corporate challenges of sustainable development. Acad. Manag. Perspect. 2002, 16, 122-131. [CrossRef]

14. Nilsson, M.; Griggs, D.; Visbeck, M. Policy: Map the interactions between Sustainable Development Goals. Nat. News 2016, 534, 320-322. [CrossRef]

15. Okraszewska, R.; Romanowska, A.; Wołek, M.; Oskarbski, J.; Birr, K. Integration of a multilevel transport system model into sustainable urban mobility planning. Sustainability 2018, 10, 479. [CrossRef]

16. Schikofsky, J.; Dannewald, T.; Kowald, M. Exploring motivational mechanisms behind the intention to adopt mobility as a service (MaaS): Insights from Germany. Transp. Res. Part A Policy Pract. 2020, 131, 296-312. [CrossRef]

17. Arias-Molinares, D.; García-Palomares, J. The Ws of MaaS: Understanding mobility as a service from a literature review. IATSS Res. 2020, 44, 253-263. [CrossRef]

18. Furuhata, M.; Dessouky, M.; Ordóñez, F.; Brunet, M.-E.; Wang, X.; Koenig, S. Ridesharing: The state-of-the-art and future directions. Transp. Res. Part B Methodol. 2013, 57, 28-46. [CrossRef]

19. Sprei, F.; Habibi, S.; Englund, C.; Pettersson, S.; Voronov, S.; Wedlin, J. Free-floating car-sharing electrification and mode displacement: Travel time and usage patterns from 12 cities in Europe and the United States. Transp. Res. Part D Transp. Environ. 2019, 71, 127-140. [CrossRef]

20. Rinne, A. The sharing economy, through a broader lens. Stanf. Soc. Innov. Rev. 2015, 4, 2015.

21. Susan, S.; Nelson, C.; Apaar, B.; Adam, C. Shared Mobility-A Sustainability E Technologies Workshop: Definitions Industry Developments and Early Understanding; Transportation Sustainability Research Center, University of California: Berkeley, CA, USA, 2015; Available online: http:/ /innovativemobility.org/wpcontent/uploads/2015/11/SharedMobility_WhitePaper_FINAL.pdf (accessed on 10 May 2020).

22. Global Shared Mobility Market Size Forecast from 2021 to 2028, by Region. Available online: https:/ / www.statista.com/statistics / 1229470/shared-mobility-market-size-worldwide-by-region/ (accessed on 8 August 2021).

23. Svegander, M. The Carsharing Telematics Market, 3rd ed.; Berg Insight: Gothenburg, Sweden, 2019.

24. Münzel, K.; Boon, W.; Frenken, K.; Vaskelainen, T. Carsharing business models in Germany: Characteristics, success and future prospects. Inf. Syst. e-Bus. Manag. 2020, 2, 1-21. [CrossRef]

25. Perboli, G.; Ferrero, F.; Musso, S.; Vesco, A. Business models and tariff simulation in car-sharing services. Transp. Res. Part A Policy Pract. 2018, 115, 32-48. [CrossRef]

26. Ciari, F.; Bock, B.; Balmer, M. Modeling Station-Based and Free-Floating Carsharing Demand: Test Case Study for Berlin. Transportation Research Record 2014, 2416, 37-47. [CrossRef]

27. Nourinejad, M.; Roorda, M. Carsharing operations policies: A comparison between one-way and two-way systems. Transportation 2015, 42, 497-518. [CrossRef]

28. Secinaro, S.; Brescia, V.; Calandra, D.; Biancone, P. Employing bibliometric analysis to identify suitable business models for electric cars. J. Clean. Prod. 2020, 264, 121503. [CrossRef]

29. Sarasini, S.; Linder, M. Integrating a business model perspective into transition theory: The example of new mobility services. Environ. Innov. Soc. Transit. 2018, 27, 16-31. [CrossRef]

30. Ma, J.; Xu, M.; Meng, Q.; Cheng, L. Ridesharing user equilibrium problem under OD-based surge pricing strategy. Transp. Res. Part B Methodol. 2020, 134, 1-24. [CrossRef]

31. Xing, J.; Liu, Z.; Wu, C.; Chen, S. Traffic Volume Estimation in Multimodal Urban Networks Using Cell Phone Location Data. IEEE Intell. Transp. Syst. Mag. 2020, 11, 93-104. [CrossRef]

32. Nooraini, R. Algorithm Analysis of Definite Integration by Using Desk Check Method. J. Inform. Bisnis 2013, 1, 50-55.

33. Rahman, R.; Alarifi, A.H.E.; Eden, R.; Sedera, D. Archival analysis of service desk research: New perspectives on design and delivery. In Proceedings of the 25th Australasian Conference on Information Systems, Auckland, New Zealand, 8-10 December 2014; Wang, W., Pauleen, D., Eds.; ACIS: Auckland, New Zealand; Auckland University of Technology: Auckland, New Zealand, 2014; pp. 1-10. 
34. Gandhi, A.; Sucahyo, Y.G.; Ruldeviyani, Y. Investigating the Protection of Customers Personal Data in the Ridesharing Applications: A Desk Research in Indonesia. In Proceedings of the 15th International Conference on Electrical Engineering/Electronics, Computer, Telecommunications and Information Technology (ECTI-CON), Chiang Rai, Thailand, 18-21 July 2018 ; pp. 118-121.

35. Woolley, M. Using statistics for desk research. Aslib Proc. 1992, 44, 227-233. [CrossRef]

36. Mauksch, S.; von der Gracht, H.A.; Gordon, J.T. Who is an expert for foresight? A review of identification methods. Technol. Forecast. Soc. Chang. 2020, 154, 119982. [CrossRef]

37. Wright, G.; O’Brien, F.; Meadows, M.; Tapinos, E.; Pyper, N. Scenario planning and foresight: Advancing theory and improving practice. Technol. Forecast. Soc. Chang. 2020, 159, 120220. [CrossRef]

38. Loveridge, D. Experts and foresight: Review and experience. Int. J. Foresight Innov. Policy 2004, 1, 33-69. [CrossRef]

39. Wiacek, M. Implementation of innovative changes in polish enterprises outline of perspectives, review of research. Int. J. Bus. Manag. Econ. Rev. 2020, 3, 78-96. [CrossRef]

40. Mishin, V.M. Research of Control Systems; Textbook for Universities; Unity-Dana: Moscow, Russia, 2003.

41. Report of Shared Mobility Market. Available online: https://www.globenewswire.com/en/news-release/2020/12/10/2143121 /0/en/Global-Shared-Mobility-Market-Size-Trends-Will-Reach-to-USD-238-03-billion-by-2026-Facts-Factors.html (accessed on 9 August 2021).

42. Yuan, Z.; Xiao, Z.; Dai, Z.; Huang, J.; Zhang, Z.; Chen, Y. Modelling the effects of Wuhan's lockdown during COVID-19, China. Bull. World Health Organ. 2020, 98, 484-494. [CrossRef]

43. Closed Management in China. Available online: http://www.chinanews.com/sh/2020/02-14/9090650.shtml (accessed on 29 November 2020).

44. Xinhuanet Portal. Hygiene in Transportation. 2020. Available online: http://www.xinhuanet.com/science/2020-03/03/c_138839 270.htm (accessed on 9 May 2020).

45. COVID-19 Transportation Experiences. Available online: https://www.transformative-mobility.org/news/combating-covid-19 -the-shenzhen-bus-groups-experience (accessed on 10 May 2020).

46. Chinese Transport after COVID-19. The Paper China. Available online: https://www.thepaper.cn/newsDetail_forward_5914134 (accessed on 9 May 2020).

47. 3 Ways China's Transport Sector Is Working to Recover from COVID-19 Lockdowns. The City Fix Portal. Available online: https: / thecityfix.com/blog/3-ways-chinas-transport-sector-working-recover-covid-19-lockdowns/ (accessed on 10 May 2020).

48. Transport Arrangements for the Singapore COVID-19 Circuit Breaker Measures. Available online: https: / / landtransportguru. net/transport-arrangements-for-the-singapore-covid-19-circuit-breaker-measures/ (accessed on 13 May 2020).

49. WeMo Scooter-Sharing in Taiwan. Available online: https://www.wemoscooter.com/ (accessed on 9 August 2021).

50. Galeazzi, A.; Cinelli, M.; Bonaccorsi, G.; Pierri, F.; Schmidt, A.L.; Scala, A.; Pammolli, F.; Quattrociocchi, W. Human mobility in response to COVID-19 in France, Italy and UK. Sci. Rep. 2021, 11, 13141. [CrossRef] [PubMed]

51. How the Covid-19 Pandemic Is Changing Urban Mobility? Available online: https://www.youris.com/mobility/traffic management/how-the-covid-19-pandemic-is-changing-urban-mobility.kl (accessed on 9 August 2021).

52. Barbarossa, L. The Post Pandemic City: Challenges and Opportunities for a Non-Motorized Urban Environment. An Overview of Italian Cases. Sustainability 2020, 12, 7172. [CrossRef]

53. $£ 2$ Billion Package to Create New Era for Cycling and Walking. Available online: https://www.gov.uk/government/news/2billion-package-to-create-new-era-for-cycling-and-walking (accessed on 9 August 2021).

54. Edinburgh Announces Action Plan for Safe Walking and Cycling. Available online: https://www.polisnetwork.eu/article/ edinburgh-announces-action-plan-for-safe-walking-and-cycling/?id=122791 (accessed on 14 May 2020).

55. Dublin City Council. Overview of Covid Mobility Programme. Available online: https://www.dublincity.ie/residential/ transportation/covid-mobility-measures/overview-covid-mobility-programme (accessed on 9 August 2021).

56. Paris to Create 650 Kilometers of Post-Lockdown Cycleways, Forbs. Available online: https://www.forbes.com/sites / carltonreid/ 2020/04/22/paris-to-create-650-kilometers-of-pop-up-corona-cycleways-for-post-lockdown-travel/\#1796664854d4 (accessed on 7 May 2020).

57. Brussels Announces $20 \mathrm{~km} / \mathrm{h}$ Limits and Expanded Bike Network. Available online: https://www.polisnetwork.eu/article/ brussels-announces-20km-h-limits-to-give-more-space-to-people/ (accessed on 7 May 2020).

58. NYC to Close 40 Miles of Streets to Give Walkers More Space. Bloomberg. Available online: https://www.bloomberg.com/ news / articles / 2020-04-27/nyc-to-hire-1-000-people-to-trace-contacts-of-covid-19-positive (accessed on 7 May 2020).

59. Montréal: Pour des Villes Plus Solidaires et Plus Ecologiques. Le Monde. Available online: https://www.lemonde.fr/smartcities/article/2020/06/17/valerie-plante-maire-de-montreal-pour-des-villes-plus-solidaires-et-plus-ecologiques_6043219_48 11534.html (accessed on 8 August 2021).

60. Pop-Up Bike Lanes: A Rapidly Growing Transport Solution Prompted by Coronavirus Pandemic. Available online: https://www. uci.org/news/2020/pop-up-bike-lanes-a-rapidly-growing-transport-solution-prompted-by-coronavirus-pandemic (accessed on 7 May 2020).

61. $131 \mathrm{~km}$ of Temporary Bicycle Lanes to Support Safe Travel in Mexico City. Available online: https:/ / www.covidmobilityworks. org/responses / 130-km-of-temporary-bicycle-lanes-to-support-safe-travel-in-mexico-city-2ea581c6cb (accessed on 7 May 2020).

62. Car Sharing Provider Free Now. Carsharing during Pandemic. Available online: https://www.share-now.com/de/en/coronacarsharing-facts-figures/ (accessed on 10 July 2021). 
63. Gaber, H.R.; Elsamadicy, A.M. What drives customers to continue using ride-sharing apps during the COVID-19 pandemic? The case of Uber in Egypt. Cogent Bus. Manag. 2021, 8, 1944009. [CrossRef]

64. Kaur, G. The Impact of Covid-19 Pandemic on Uber's Ridesharing Activities. Jyväskylä University of Applied Sciences, 2021. Available online: https: / /www.theseus.fi/bitstream/handle/10024/499634/Thesis_Kaur_Gurpreet $\% 20 \% 282 \% 29$.pdf?sequence= 2\&isAllowed=y (accessed on 15 August 2021).

65. McKenzie, G. Urban mobility in the sharing economy: A spatiotemporal comparison of shared mobility services. Comput. Environ. Urban Syst. 2020, 79, 101418. [CrossRef]

66. Jiao, J. (Ed.) Why does shared mobility exist? A critical review of theories behind shared economy. In Shared Mobility; Elsevier: Amsterdam, The Netherlands, 2021; pp. 11-20.

67. Mont, O.; Kane Curtis, S.; Voytenko Palgan, Y. Organisational Response Strategies to COVID-19 in the Sharing Economy. Sustain. Prod. Consum. 2021, 28, 52-70. [CrossRef] 